\title{
DILEMA SKIM MURÂBAHAH PADA PERBANKAN SYARIAH
}

\author{
Syukri Iska \\ Jurusan Syariah STAIN Batusangkar \\ Jl. Jend. Sudirman No. 137 Kuburajo Limo Kaum Batusangkar, 27213 \\ e-mail: syukri.iska@yahoo.co.id
}

\begin{abstract}
Abstrak: Kesemarakan pertumbuhan perbankan syariah terutama di negaranegara Muslim pada beberapa dekade terakhir tidak dapat dipungkiri. Namun di balik pertumbuhan tersebut bank syariah sering dikritik hanya sekadar ganti "baju" dengan klaim bahwa bank ini mengambil beberapa konsep dari dari bank konvensional kemudian menggantikannya dengan idiom-idiom yang ada pada fiqih muâmalah. Tulisan ini memaparkan penjelasan terhadap pertanyaan tentang keberadaan bank syariah dengan merujuk pada skim murâbahahah, bagaimana perasaan dan perbedaan antara kedua sistem Islam dan konvensional, serta implikasi sistem perbankan Islam dalam transaksi ekonomi yang menyeluruh. Penulis berargumen bahwa kendati skim murâbahah bukan merupakan instrumen ideal untuk mencapai tujuan riil ekonomi Islam, skim murâbahah ini ternyata mengandung banyak persoalan, terutama kalau dilihat dalam perspektif syariah secara puristik ataupun menurut paradigma tentang bank.
\end{abstract}

Abstract: The Dilemma of Murabahah Skim in Shari'a Banks. The flourishing development of Shari'a Banks especially in Islamic countries for the last few decades are undeniable. However, despite such tremendous development it has often been criticized for being only changing suit claiming that it has taken some conventional system concepts which are then modified in acoordance with idioms found in Islamic jurisprudence discourse. This paper then sheds some lights on some questions of the existence of Shari'a Banks with specific reference to murâbahah skim, how the two system similar to or different from each other, as well as the implication of the Islamic banking system in the general economic transaction. The author argues that although the murâbahah skim is not an ideal instrument in achieving the real objective of Islamic economy, its domination as an important skim, however, seems to be in dilemmatic position between the pragmatic demands of the need of pure Shari'a laws as a genuine reference and the role of banks should fulfil.

Kata Kunci: perbankan syariah, murâbahah, ekonomi Islam 


\section{Pendahuluan}

Kesemarakan perkembangan sistem ekonomi Islam saat ini dapat disandingkan dengan sistem ekonomi kapitalis yang telah lama hidup mengisi kebutuhan ekonomi masyarakat dunia. Kesemarakan itu terlihat dengan adanya kecenderungan yang sangat luar biasa pada pelaku ekonomi di mana pun berada untuk bertransaksi dengan lembagalembaga keuangan syariah, baik bank maupun non-bank. Kecenderungan itu di antaranya ditandai dengan berdirinya bank-bank syariah (Islamic banking) di mana-mana, baik di negara-negara sekuler seperti Amerika Serikat dan Singapura, maupun di negara-negara Islam atau negara yang berpenduduk mayoritas Muslim, seperti Indonesia. Di Indonesia sampai saat ini telah berdiri 4 (empat) bank umum syariah, berpuluh-puluh bank konvensional yang memiliki unit usaha syariah (dual banking system) dan beratus-ratus bank pembiayaan rakyat syariah (BPRS).

Namun di balik pertumbuhan perbankan syariah yang pesat dan menggembirakan tersebut, sering muncul perspektif miring yang menyatakan bahwa bank syariah tidak lebih hanya sekadar ganti "baju" dari bank konvensional. Stigma negatif tersebut bisa saja muncul karena ketidakpahaman umat Islam tentang bank syariah, atau bisa juga setelah memandang beberapa indikator pada bank syariah yang memang terkesan ganti "baju". Artinya, ada beberapa konsep yang pada dasarnya diambil dari bank konvensional, kemudian diganti namanya dengan idiom-idiom yang ada pada fiqih muamalah.

Sejauh mana kebenaran sinyalemen tersebut tentunya membutuhkan kajian dan pembuktian lebih jauh. Namun terlepas dari itu semua, akan diangkat sebuah persoalan saja, yakni masalah skim murâbahah yang telah menjadi skim "idola" bagi bank syariah di mana pun berada, tidak terkecuali di Indonesia, kendati bukan merupakan instrumen ideal untuk mencapai tujuan riil ekonomi Islam.

Skim murâbahah telah menguasai rata-rata 75\% dari total transaksi di bank syariah. Kenapa ini yang lebih besar? Mungkin karena alasan pragmatis, yakni karena skim ini memiliki risiko yang paling rendah dibandingkan dengan skim-skim yang lain, seperti mudhârabah. Akan tetapi di balik dominasi tersebut, skim murâbah hah ini ternyata mengandung banyak persoalan, terutama jika dilihat dalam perspektif syariah secara puristik ataupun menurut paradigma tentang bank. Di saat seperti inilah terlihat bahwa skim murâbahah berada dalam nuansa dan suasana dilematis.

\section{Pengertian Murâbahah}

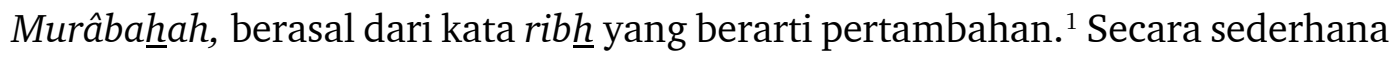
murâbahah dimaknai sebagai suatu penjualan barang seharga barang tersebut ditambah keuntungan yang disepakati. Misalnya, seseorang membeli barang kemudian menjualnya

1'Ibn Manzhur al-Afriqî, Lisân al-‘Arab, Juz II (Beirut: Dâr al-Shadr, t.t.), h. 443. 
kembali dengan keuntungan tertentu. ${ }^{2}$ Dalam ungkapan lain, Ibn Rusyd mengartikan murâbahah ini dengan jual beli barang pada harga asal dengan tambahan keuntungan yang disepakati. ${ }^{3}$

Dari pengertian yang menyatakan adanya keuntungan yang disepakati, murâbahah memiliki karakteristik, yakni si penjual harus memberi tahu kepada pembeli tentang harga pembelian barang dan menyatakan jumlah keuntungan yang ditambahkan pada biaya tersebut. ${ }^{4}$ Perhitungan keuntungan itu boleh berdasarkan jumlah harga atau kadar persentase tertentu. ${ }^{5}$

Biasanya murâbahah ini berlaku dalam keadaan pihak pembeli tidak mengetahui harga pasaran sebenarnya dan memercayai kejujuran penjual yang mengatakan modalnya dan keuntungan yang direncanakan. Rencana itu bisa saja datang dari pihak penjual sendiri yang bertujuan untuk melariskan barang jualannya dengan menawarkan kepada pembeli dengan harga tertentu dengan mengatakan biaya dan jumlah keuntungan. ${ }^{6}$ Penjual bukan saja dikehendaki menyatakan harga asal yang dibelinya, malah juga dikehendaki menyampaikan beberapa hal lain yang berkaitan, yang bisa memengaruhi harga penjualan seperti pembelian secara bertangguh karena ini akan meningkatkan harga penjualan nantinya. ${ }^{7}$

Transaksi murâbahah ini, tidak pernah secara langsung dibicarakan dalam alQur'an, kecuali tentang jual beli secara umum, laba dan rugi, serta perdagangan. Demikian juga halnya dengan hadis Rasulullah SAW. yang membicarakan langsung tentang murâbahah, kecuali tentang jual beli tangguh (bay' bi tsaman ajil), yang lazim dilaksanakan oleh Nabi SAW. dan para sahabatnya. Sebagaimana terungkap dalam sabdanya yang diriwayatkan oleh Ibn Majah dari Shuhaib al-Rûmî bahwa Rasulullah SAW. bersabda:

${ }^{2}$ Ibn 'Abidîn, Radd al-Mukhtâr 'alâ al-Ardh al-Mukhtâr, Juz IV (t.tp.: t.p., t.t), h. 19.

${ }^{3}$ Ibn Rusyd, Bidâyah al-Mujtahid wa Nihâyah al-Muqtashid, Juz II (Kairo: Syarikah Maktabah wa Mathba'ah Musthafa al-Bâbî al-Halâbî wa Auladih, 1981), h. 210.

${ }^{4} I b i d .$, h. 293. Menurut Ab. Mumin Ab. Ghani, Sistem Kewangan Islam dan Pelaksanaannya di Malaysia (Kuala Lumpur: Jabatan Kemajuan Islam Malaysia, 1999), h. 410 yang dikutipnya dari al-Madkhal al-Fiqh al-'Âmm karya al-Zarqa', cara jual beli Murâbahah ini tergolong dalam kategori Buyâ' al-Amânah. Dalam kitab tersebut diungkapkan bahwa Bay' itu terbagi kepada dua kategori, pertama, Bay' al-Musawwamah, yaitu harga jual tidak dikaitkan dengan harga pembelian barang, dan masing-masing pihak bebas melakukan tawar menawar terhadap harga barang tersebut. Kedua, Bay' al-Amânah, yaitu penentuan harga jual barang terikat dengan harga pembelian barang dan harus menyampaikannya kepada si pembeli. Salah satu bentuknya adalah murâbahah. Lihat al-Zarqa', al-Madkhal al-Fiqh al-Âmm (al-Fiqh al-Islâmi fì Tsawbih al-Jadîd, Juz I (Beirut: Dâr al-Fikr, 1968), h. 377.

${ }^{5}$ Ibn Rusyd, Bidâyah al-Mujtahid, Juz II, h. 213.

${ }^{6}$ Muhamammad Idrîs al-Syâfi'î, al-Umm, Juz III (Beirut: Dâr al-Ma'rifah, 1973), h. 39.

${ }^{7}$ Abû Bakr Ibn Mas'ûd Al-Kasânî, al-Badâ'i wa al-Shana'i fî Tartîb al-Syara'i, Juz VII (Beirut: Dâr al-Kitab al-Arabî, t.t.), h. 3200. 
MIQOT Vol. XXXV No. 2 Juli-Desember 2011

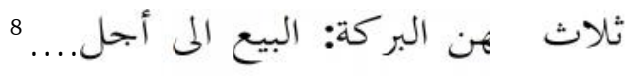

"Tiga hal yang di dalamnya terdapat keberkahan; (salah satunya) jual beli secara tangguh...."

Para imam mazhab, seperti Malik dan Syâfi'î secara khusus mengatakan bahwa jual beli murâbaḩah itu boleh, kendati tanpa memperkuat dalilnya dengan nashsh, melainkan menyamakannya dengan jual beli tangguh sebagaimana ungkapan hadis di atas. ${ }^{9}$ Imam Malik mendasari murâbahahah dengan amalan penduduk Madinah. Imam Syâfiîi tanpa teks syariah, namun secara jelas mengungkapkan "Jika seseorang menunjukkan suatu barang kepada orang lain dan berkata, belikan barang (seperti) ini untukku dan aku akan memberimu keuntungan sekian, lalu orang itu pun membelinya, maka jual beli ini adalah sah."10

Bagaimana halnya dengan biaya lain akibat dari transaksi jual beli murâbahah ini? Para ulama mazhab berbeda pendapat tentang hal itu. Ulama mazhab Maliki membolehkan biaya-biaya yang langsung terkait ataupun tidak terkait langsung dengan transaksi jual beli tersebut, dibebankan kepada harga jual barang. Sedangkan ulama mazhab Syâfiî̀ membolehkan pembebanan biaya yang secara umum timbul dalam suatu transaksi jual beli, kecuali biaya tenaga kerjanya sendiri karena komponen ini termasuk dalam keuntungannya. Begitu juga biaya-biaya yang tidak menambah nilai barang tidak boleh dimasukkan sebagai komponen biaya. ${ }^{11}$

Ulama mazhab Hanafi membolehkan pembebanan biaya-biaya yang secara umum timbul dalam suatu transaksi jual beli, namun tidak dibolehkan terhadap biaya-biaya yang memang semestinya dikerjakan oleh si penjual, ${ }^{12}$ kecuali pembeli membenarkannya. ${ }^{13}$ Adapun ulama dari mazhab Hanbali menyatakan bahwa semua biaya langsung ataupun tidak langsung dapat dibebankan pada harga jual selama biaya-biaya itu harus dibayarkan kepada pihak ketiga dan akan menambah nilai barang yang dijual. ${ }^{14}$ Mazhab Maliki membagi biaya pembelanjaan tambahan itu kepada tiga kategori. Kategori pertama adalah semua pembelanjaan yang boleh dicampurkan kepada harga biaya dan ia menjadi dasar untuk perhitungan keuntungan yaitu pembelanjaan yang secara langsung memberikan pengaruh

${ }^{8} \mathrm{Ibn}$ Majah, Sunan Ibn Majah, Juz II (Kairo: Mathba'ah Dâr Ihya` al-Kutub al-'Arabiyah, t.t.), h. 768 .

'Lihat al-Kasânî, al-Badâ'i wa al-Shana'i, Juz VII, h. 3192.

${ }^{10}$ Al-Syâfiî̀, al-Umm, Juz III, h. 33.

${ }^{11}$ Al-Syarbînî, Mughni al-Muhtâj 'alâ Ma'ârif Ma'âni Alfâzh al-Minhâj (Kairo: Syarikah Maktabah wa Mathba'ah Musthafa al-Bâbî al-Halâbî wa Awladih, 1958), h.78.

${ }^{12}$ Burhan al-Dîn al-Marghinânî, al-Hidâyah Syarh Bidâyah al-Mubtadi, Juz III (Kairo: Syarikah Maktabah wa Mathba'ah Musthafa al-Bâbî al-Halâbî wa Auladih, t.t.), h. 56; alKasânî, al-Badâ'i wa al-Shana'i, Juz VII, h. 3199.

${ }^{13}$ Abd al-Rahmân al-Jazîrî, Kitâb al-Fiqh 'alâ al-Madzâhib al-Arba'ah, Juz II (Bairut: Dâr Ihya' al-Turats al-'Arabi, 1986), h. 280.

${ }^{14}$ Manshûr bin Yûsuf al-Bahûtî, Kasyf al-Qinâ' 'an Matîn al-Iqnâ (Beirut: Dâr al-Fikr, 1982), h. 234; Abû Muhammad bin Ahmad Ibn Qudamah, al-Mughnî, Juz IV (Riyadh: Riasah Idârah al-Buhuts al-'Ilmiyyah wal al-Ifta' wa al-Da'wah wa al-Irsyâd, 1401 H), h. 201. 
kepada barang. Kedua, pembelanjaan yang boleh dicampurkan dengan harga biaya tetapi tidak boleh dijadikan dasar perhitungan keuntungan yaitu pembelanjaan yang tidak memberi pengaruh langsung terhadap barang itu tetapi terpaksa dilakukan karena penjual tidak mampu melakukannya sendiri, seperti biaya pengangkutan atau penyimpanan. Ketiga, pembelanjaan yang tidak boleh dimasukkan ke dalam penentuan harga penjualan dan tidak boleh juga dijadikan dasar perhitungan keuntungan, yaitu pembelanjaan yang tidak memberi pengaruh pada barang itu dan ia tidak bisa dilakukan sendiri oleh penjual. ${ }^{15}$

Dari perbedaan pendapat di antara ulama mazhab tersebut, terlihat adanya kesamaan yang dapat dipahami, yakni mereka sama-sama tidak membolehkan pembebanan biaya tidak langsung bila tidak menambah nilai barang.

Jual beli dengan bentuk murâbaḩah ini dapat dalam bentuk pesanan, yang diistilahkan oleh Imam Syâfiî̀ dengan al-amr bi al-syirâ'.${ }^{16}$ Juga dapat disamakan dengan Bay 'bi Tsaman 'Ajil atau Bay' Mu 'ajjal (jual beli yang barangnya diserahkan segera dan pembayarannya ditangguhkan atau dilakukan secara berangsur). ${ }^{17}$ Jadi, murâbaḩah merupakan salah satu bentuk jual beli yang dihalalkan. Untuk itu pada dasarnya, ia harus sesuai dengan rukun dan syarat jual beli, seperti barang yang diperjualbelikan itu adalah barang yang sudah jelas adanya. Kendati ada juga persyaratan tersendiri dalam murâbahah ini, di antaranya:

1. Penjual harus menyatakan modal sebenarnya dari barang tersebut;

2. Harus ada persetujuan kedua belah pihak yang bertransaksi tentang kadar keuntungan yang ditetapkan sebagai kelebihan terhadap harga modal;

3. Seandainya kadar harga modal barang yang disampaikan tidak sesuai dengan yang sebenarnya, maka si pembeli boleh membatalkan kontrak tersebut. ${ }^{18}$

\section{Transaksi Murâbahah di Perbankan Syariah}

Seperti di perbankan syariah lain, ${ }^{19}$ transaksi murâbahah merupakan suatu transaksi terbesar di perbankan syariah Indonesia, karena dipandang sebagai transaksi yang memiliki tingkat risiko teringan dibandingkan dengan yang lain, seperti mudhârabah. ${ }^{20}$ Secara umum, skema penerapan murâbahah dalam perbankan syariah antara bank dengan nasabah adalah:

${ }^{15}$ Ibn Rusyd, Bidâyah al-Mujtahid, Juz II, h. 214; al-Jazîrî, Kitâb al-Fiqh 'alâ al-Madzâhib al-Arba'ah, Juz II, h. 279.

${ }^{16}$ Al-Syâfi'î, al-Umm, Juz III, h. 39.

${ }^{17}$ Kedua jenis jual beli tersebut termasuk ke dalam kategori jual beli utang bertangguh (Bay ${ }^{6}$ bi Dayn Mu'ajjal), sebagaimana dinyatakan oleh Ibn 'Arabi dalam Ahkâm al-Qur'ân, Juz I (Kairo: 'Îsa al-Bâbî al-Halâbî wa Syurakah, 1967), h. 241.

${ }^{18}$ Lihat Ibn Qudamah, al-Mughnî, Juz IV, h. 200 dan 206-207.

${ }^{19}$ Pembiayaan murâbahah pada Dubai Islamic Bank mencapai 82\% dan pada IDB mencapai 73\%, silahkan lihat Abdullah Saeed, Islamic Banking and Interest: a Study the Prohibition of Riba and its Contemporary Interpretation (Leiden: E.J. Brill, 1996), h. 78. 
1. Nasabah yang memerlukan barang datang ke bank untuk melakukan transaksi murâbahah;

2. Nasabah menjelaskan spesifikasi barang yang diperlukannya kepada bank;

3. Bank melakukan pemesanan barang tersebut kepada supplier;

4. Bank melakukan pembayaran secara tunai kepada supplier;

5. Setelah itu supplier/bank menyerahkan barang tersebut kepada nasabah;

6. Nasabah melakukan pembayaran secara tunai atau cicilan kepada bank.

Dari skema di atas, terlihat bahwa bank secara langsung membeli barang kepada supplier dan menyerahkannya kepada nasabah. Dalam realitasnya, bank sering mewakilkan kepada nasabah untuk melakukan transaksi dengan supplier. Akan tetapi, bagaimana pun, peran bank adalah sebagai pedagang barang, dan didasari itulah bank mendapatkan keuntungan. Realitas seperti itu agak terasa rancu, bahwa pada prinsipnya fungsi bank bukanlah pedagang barang, melainkan penyedia jasa dalam memberikan fasilitas pembiayaan, atau dalam makna umum, bank sebagai penghimpun dan penyalur dana (intermediary). Namun kenyataannya, skim murâbahah inilah yang terbesar.

Jenis barang yang diperjualbelikan dalam transaksi murâbahhah ini ada yang berbentuk konsumtif, seperti untuk kendaraan bermotor, rumah dan sebagainya. Ada juga dalam bentuk produktif, seperti yang pernah dilakukan oleh salah satu bank syariah di Indonesia, dalam pembelian mesin-mesin untuk pabrik, kapal tongkang dari China, mesin pembuat makanan ayam, penggemukan lembu, ${ }^{21}$ dan sebagainya. Dalam aktivitas jual beli dengan cara mewakilkan kepada nasabah untuk memilih barang yang diinginkan dan tempat pembeliannya, disebut dengan sistem akad wakâlah. Pihak bank seterusnya akan meminta invoice (faktur) sebagai bukti pembelian barang tersebut. ${ }^{22}$

Akad wakâlah dilakukan sebelum berlakunya akad murâbahah secara formal. Sebelum akad formal itu dilaksanakan, perlu diadakan pembicaraan awal antara nasabah dengan pihak bank tentang kualifikasi, harga barang dan kemungkinan nilai mark-upnya yang dapat dirundingkan. ${ }^{23}$ Setelah mencapai kesepakatan, nasabah yang mewakili pihak bank

${ }^{20}$ Secara akurat tidak ditemukan data pasti berapa banyak skim murâbahah ini dari total skim yang ada di bank syariah.

${ }^{21}$ Hasil wawancara dengan salah seorang representasi salah satu bank syariah, dan bank juga pernah menawarkan murâbahah produktif dengan bentuk skim mudhârabah, namun penabung tidak bersedia.

${ }^{22}$ Akad wakâlah dilakukan seharusnya sebelum akad murâbahah terjadi, karena bank sebagai penjual yang tentunya harus telah memiliki barang itu sepenuhnya, barulah boleh dijual kepada penabung dengan akad murâbahah. Lihat Syukri Iska, "Dilematis Lembaga Perbankan Syariah dalam Kultur Minangkabau," dalam Jurtnal Ilmiah Syariah (Juris) STAIN Batusangkar, Vol. 5, No. 1/ 2006.

${ }^{23}$ Akad wakâlah berdasarkan fatwa DSN MUI No. 10/DSN-MUI/IV/2000 dinyatakan boleh, selagi memenuhi ketentuan dan syarat-syarat yang telah ditetapkan, seperti barang atau objek yang diwakilkan itu harus jelas oleh pihak yang mewakili, dan tentunya harus sesuai dengan kesepakatan tentang objek yang diwakilkan tersebut. Berdasarkan fatwa DSN MUI No. 04/DSN- 
akan membeli barang sesuai dengan pembicaraan dan kesepakatan kedua belah pihak. Berdasarkan call memo atau invoice yang diserahkan oleh penabung, akan dibuat berita acara pembelian secara formal, seperti jenis barang, harga barang, dan nilai mark-upnya yang ditetapkan (diistilahkan juga dalam transaksi itu dengan margin atau keuntungan bank), di samping ada juga uang muka (urbûn). ${ }^{24}$

Jika diteliti naskah transaksi atau akad murâbahah pada salah satu Bank Syariah di Indonesia, maka jumlah pembiayaan murâbaḩah ialah harga barang di supplier, ditambah margin dan dikurangi uang muka (urbûn). Hal ini memberikan kesan bahwa akad murâbahah itu diperhitungkan terhadap jumlah pembiayaan bank, bukan terhadap harga barang sehingga sukar membedakannya dengan sistem perbankan konvensional. Kendati dibantah, saat dimintakan klarifikasi kepada pihak bank syariah tersebut. ${ }^{25}$ Salah seorang karyawannya menyatakan bahwa perhitungan akad murâbahah tetap terhadap harga barang di pasar, ditambah dengan margin, walaupun ada uang muka atau urbun. Keberadaan uang muka, menurut karyawannya, tidak akan mengurangkan harga jual. ${ }^{26}$ Perhitungan margin atau mark-up berdasarkan kepada sisa pembiayaan (harga barang awal dikurangi uang muka) yang dilakukan secara internal. ${ }^{27}$ Ungkapan terakhir inilah yang membuat perhitungannya sama dengan bank konvensional.

Sebagai gambaran, penulis mengemukakan bentuk perhitungan pembiayaan murâbahah yang diambil dari sebuah naskah akad murâbahah pada salah satu bank syariah, dalam pembiayaan pembelian bahan bangunan rumah:

\begin{tabular}{|c|lll|}
\hline a. & Nilai objek pembiayaan & $:$ & Rp. 199.000.000,- (penggenapan) \\
\hline b. & Self Financing/Urbun & $:$ & Rp. 129.000.000,- (penggenapan) \\
\hline c. & Pembiayaan Bank & $:$ & Rp. $70.000 .000,-$ \\
\hline d. & Margin yang disepakati & $:$ & Rp. $70.000 .000,-$ \\
\hline e. & Maksimum Pembiayaan & $:$ & Rp. $140.000 .000,-$ \\
\hline
\end{tabular}

Jangka masa yang diambil untuk masa angsuran ialah 120 bulan atau selama 10 tahun, dengan nilai margin diperhitungkan 10 peratus per tahun.

Dari gambaran bentuk transaksi di atas, marginnya diperhitungkan berdasarkan

MUI/IV/2000, jika bank mewakilkan kepada nasabah untuk pembelian barang, akad jual beli murâbahah harus dilakukan setelah barang secara prinsip menjadi milik bank. Silahkan lihat Himpunan Fatwa Dewan Syariah Nasional MUI, Edisi Revisi Tahun 2006.

${ }^{24}$ Wawancara dengan dua orang pegawai bank syariah yang berbeda, dan pengalaman empirik sebagai nasabah di salah satu bank syariah.

${ }^{25}$ Wawancara dengan seorang pimpinan salah satu bank syariah.

${ }^{26}$ Ibid.

${ }^{27}$ Ibid. 
kepada nilai pembiayaan oleh Bank (10\% x Rp. 70 juta $\times 10$ tahun $=$ Rp. 70 juta), bukan kepada nilai objek pembiayaan (10\% x Rp. 199 juta x 10 tahun $=$ Rp. 199 juta). Pada hal dalam jual beli, keuntungan atau margin itu diperhitungkan kepada nilai harga barang di pasar, bukan diperhitungkan dari kadar dana bank yang digunakan dalam biaya pembelian barang tersebut. Inilah yang memberikan kesan tidak adanya perbedaan perhitungan kelebihan peminjaman uang pada bank konvensional yang perhitungannya berdasarkan kepada kadar pinjaman, dan inilah yang terkategori riba.

Berdasarkan ilustrasi di atas, sesuai dengan aturan syariahnya, jumlah margin adalah Rp. 199 juta. Karena adanya urbun dari nasabah sebesar Rp. 129 juta, maka jumlah margin tersisa adalah Rp. 70 juta. Untuk itu jumlah uang yang akan diangsur oleh nasabah adalah margin sisa ditambah jumlah pembiayaan dari bank (Rp. 70 juta + Rp. 70 juta $=$ Rp. 140 juta). Setelah dilakukan perhitungan syariah, terlihat bahwa nilai nominal utang nasabah yang akan diangsur selama 10 tahun terlihat sama dengan pola perhitungan pertama yang disinyalir sama dengan perhitungan bank konvensional di atas, namun dasar perhitungan marginnya berbeda, yakni pola konvensional diperhitungkan kepada nilai pembiayaan bank, sedangkan pola syariah perhitungan margin kepada nilai harga barang awal di pasar (nilai objek pembiayaan).

Dalam bentuk lain, sistem perhitungan yang dilakukan sesuai dengan hakikat akad murâbaḩah, yaitu jual beli barang yang harganya terdiri dari harga pembelian di pasaran ditambah dengan margin dan dibayar secara angsur atau tunai. Berarti, perhitungan margin itu harus diperhitungkan kepada Rp. 199 juta, yaitu $10 \%$ x Rp. 199 juta $\times 10$ tahun = Rp. 199 juta (sebagaimana telah diilustrasikan juga di atas). Bagaimana dengan keuntungan bank akibat dari pembiayaan sebanyak Rp. 70 juta itu? Pertanyaan yang sama juga akan muncul, bagaimana dengan uang muka atau urbûn dari penabung sebanyak Rp. 129 juta itu, apakah penabung akan mendapat pembagian keuntungan? Kedua-duanya tentu akan mendapat perhitungan keuntungan.

Dengan demikian margin sebanyak Rp. 199 juta itu dibagi secara proporsional antara bank dan penabung, akibat dari keikutsertaan dana pembiayaan dari kedua belah pihak. Tampaknya, telah terjadi dua akad, yaitu adanya musyârakah dalam akad murâbahahah, atau murâbah̆ah wa musyârakah. Walaupun dalam perhitungannya agak sulit, namun pihak bank akan menerima hal yang sama dengan perhitungan yang lazim dilakukan, seperti yang berlaku pada contoh di atas. Pihak nasabah sendiri, secara riil tidak akan menerima nominal keuntungan tersebut, karena pembagiannya ditempatkan untuk membayar angsuran kepada bank saja. Dengan demikian, dalam akad tersebut telah terlaksana hakikat murâbaḩah yang sebenarnya dan terbukti berbeda secara signifikan dengan sistem peminjaman uang yang ada pada bank konvensional.

Persoalan riil yang ada pada bank syariah, sebagaimana ditemukan di atas, kalau dibiarkan terus oleh pihak perbankan syariah, dikhawatirkan akan semakin memperkuat adanya sinyalemen atau penilaian negatif masyarakat yang memandang bahwa tidak 
ada perbedaan antara sistem bank syariah dengan bank konvensional. Berapa ketentuan margin atau keuntungan penjualan barang, dan apa yang mendasari perhitungan nilai margin tersebut?

Menurut pihak bank syariah bahwa kadar keuntungan atau mark-up yang dibebankan bergantung kepada berapa lama masa angsuran yang diinginkan atau disepakati dengan penabung. Artinya, harga barang akan semakin tinggi karena masa pembayaran angsuran/ kredit yang semakin lama. Apa yang dilakukan oleh bank syariah di atas tentang perbedaan harga jual barang dengan transaksi murâbaḩah ini ialah wajar karena berbedanya masa pembayaran atau angsuran. Hal ini telah berlaku pada seluruh perbankan syariah, karena cara seperti itulah yang dapat memperlihatkan hakikat dan prinsip sebuah bank. Persoalannya, bagaimanakah Islam memandang perbedaan harga jual barang karena perbedaan masa angsuran pembayaran tersebut?

Secara jelas (syarîh) al-Qur'an dan Sunnah tidak pernah menggariskan ketentuan hukum tentang harga kredit yang lebih tinggi dalam jual beli karena pembayaran yang ditunda, kecuali pendapat para fukaha klasik dan ulama kontemporer. Para fukaha seperti Imam Malik dan Imam Syâfiî, tidak setuju dengan harga kredit yang lebih tinggi dibandingkan harga pembayaran tunai, walaupun para pengikut mazhab Syâfiî̀ membolehkannya. ${ }^{28}$ Ketidakbolehan menaikkan harga barang karena masa ialah karena masa bukanlah uang atau objek yang dapat menjadi nilai acuan kenaikan dalam suatu utang. Faqih mazhab Hanafi, Imam al-Syaibânî, sebagaimana dikemukakan oleh Abdullah Saeed, tidak menyetujui penjualan dengan harga lebih murah untuk tunai dan lebih mahal untuk kredit. Seperti juga pendapat al-Râzî yang mengomentari mengenai ayat-ayat riba, menolak anggapan bahwa masa yang diberikan untuk pembayaran dapat menjadi acuan bagi kenaikan harga, sebab masa bukanlah barang atau sesuatu yang ditunjuk, untuk dijadikan nilai acuan. ${ }^{29}$

Seorang ulama Arab Saudi, Abd Allah ibn Baz, dalam fatwanya dan Rafiq al-Mishrî dalam pembahasannya yang agak berani menjelaskan bahwa pembayaran tunda dimana tambahan diberikan karena penundaan pembayaran tersebut, maka berarti utang sama dengan bunga. Menurutnya lebih jauh, bunga ini mencerminkan perbedaan antara harga tunai dengan harga kredit. ${ }^{30}$

Pada masa ini pun, para pemerhati murâbahah seperti al-Kaff berpendapat bahwa kenaikan harga karena masa ialah riba. Council of Islamic Ideology (CII) Pakistan menyatakan

\footnotetext{
${ }^{28}$ Abdullah Saeed, Islamic Banking and Interest, h. 78. Lihat lebih jauh al-Syâfi'î, al-Umm, Juz III, h. 31-35; Muhammad al-Syaukânî, Nail al-Authâr, Juz V (Kairo: Maktabah al-Da'wah al-Islâmiyyah, t.t.), h. 152 .

${ }^{29} I b i d .$, h. 80-81; al-Râzî, al-Tafsîr al-Kabîr, Juz VII (Kairo: al-Matba'ah al-Bahiyyah, 1938), h. 97.

${ }^{30} I b i d .$, h. 82; Kuwait Finance House, al-Fatâwâ al-Syar'iyyah fí al-Masấil al-Iqtishâdiyyah, Kuwait: KFH, 1985-1986 \& 1986-1987, dan al-Mishr, Masraf al-Tanmiyyat al-Islâmiy (Beirut: Mu'assasat al-Risâlah, 1997), h. 195.
} 
bahwa keraguan mungkin muncul karena tambahan yang diterima penjual dalam jual beli dengan pembayaran tunda (yaitu sebagai pengganti tenggang masa pembayaran yang diberikan untuk pembeli), sehingga tambahan semacam ini dapat menyerupai riba. ${ }^{31}$ Dalam sisi pandang yang berbeda, beberapa ulama dan pakar hukum Islam mengemukakan bahwa perbedaan harga barang tunai dengan angsuran dibolehkan. Di antaranya pendapat ulama mazhab Hanbali, Ibn al-Qayyim, yang mengatakan "ketika seseorang menjual sesuatu dengan harga seratus bila dibayar tunda, atau dengan harga lima puluh bila dibayar tunai, maka tidak ada haram dalam hal ini. ${ }^{32}$ Jika semenjak awal si penjual mengatakan bahwa ia akan menjual barang dengan harga sekian dan sekian untuk kredit, tidak ada masalah dalam hal ini. ${ }^{33}$

Ada beberapa hal yang dapat dijadikan dasar kebolehan harga yang lebih tinggi akibat pembayaran tunda atau angsur:

a. Tidak ada satupun teks-teks syariah yang melarangnya.

b. Adanya perbedaan antara uang yang tersedia sekarang dengan yang tersedia di masa datang, seperti yang dikatakan oleh 'Alî al-Khafif, seorang faqih kontemporer, "kebiasaannya uang yang dibayarkan kontan mempunyai nilai yang lebih tinggi dari uang yang diberikan pada masa datang".

c. Kenaikan harga ini bukan sebagai akibat penjelasan tunda pembayaran. Ini berarti tidak sama dengan riba yang diharamkan al-Qur'an.

d. Kenaikan harga dikenakan saat penjualan, bukan setelah penjualan berlaku.

e. Kenaikan harga disebabkan oleh faktor-faktor yang memengaruhi pasar, seperti permintaan dan penawaran, naik turunnya daya beli dan nilai uang sebagai akibat inflasi dan deflasi.

f. Pedagang sedang melakukan suatu aktivitas dagang yang produktif. ${ }^{34}$

g. Rafiq al-Mishrî menambahkan bahwa penjual boleh menetapkan harga berapa pun yang dikehendakinya, sebagaimana dikatakannya, "Penjual pada prinsipnya, bebas untuk menetapkan harga barang-barangnya. Jika harga-harga ini terlalu tinggi, pembeli boleh memilih untuk membelinya atau mencari pengganti, atau penjual lain yang sesuai." 35

Dalam versi lain, Warkum Sumitro mengemukakan bahwa ada beberapa konsep yang menjadi dasar penghitungan mark-up pada bank syariah, yaitu:

${ }^{31} I$ Ibid., h. 81. Dikutipnya dari al-Kaff, Does Islam Assign Any Value, dan CII., Consolidated Recommendations on the Islamic Economic System (Islamabad: Council of Islamic Ideology, 1983).

${ }^{32}$ Syauqy Ismâ‘îl Syihata, Nazhariyyat al-Muhâasabah al-Mâliyyah min Mandûrin Islâmi (Kairo: al-Zahra li al-I'lam al-'Arabi, 1987), h. 104.

${ }^{33}$ Syaukânî, Nail al-Authâr, Juz V, h. 152.

${ }^{34}$ Syihata, Nazhariyyat al-Muhâsabah, h. 104-107.

${ }^{35}$ Al-Mishrî, Masraf al-Tanmiyyat al-Islâmi, h. 187. 
a. Margin atau mark-up merupakan bentuk biaya yang terdiri dari biaya administrasi dan tingkat keuntungan yang layak.

b. Biaya administrasi diperhitungkan dari beban bank syariah untuk membayar semua biaya operasional yang ada pada semua bank.

c. Tingkat keuntungan yang layak ditentukan berdasarkan hasil tawar menawar nasabah dan bank syariah dengan melihat kepada kemampuan nasabah tersebut. ${ }^{36}$

Memastikan perbedaan nilai mata uang antara masa pembayaran tunai dengan masa pembayaran tunda atau kredit, sehingga menjadi dasar untuk meninggikan harga kredit, itu jelas menafikan keberadaan sesuatu yang tidak akan mungkin dapat dipastikan oleh manusia, termasuk dalam hal ini kemungkinan nilai mata uang. Kemungkinan nilai mata uang itu bisa saja akan menurun dibandingkan sebelumnya (disebut inflasi), namun bisa juga akan menjadi naik, sehingga harga barang menjadi murah (disebut deflasi). Pada saat adanya kepastian inflasi pada masa yang akan datang itulah, dinyatakan oleh Adiwarman A. Karim bahwa time value of money tidak sesuai dalam Islam. ${ }^{37}$

Dengan demikian, apakah tidak dibolehkan menaikkan harga barang akibat tertundanya pembayaran/kredit, sebagaimana yang telah dipraktikkan oleh bank-bank konvensional di dunia ini? Itu jelas tidak rasional dan tidak realistis. Bagaimana mungkin pihak bank akan bergerak secara baik jika tidak menjalankan hal di atas atau akan menimbulkan kemudaratan pada bank. Kalau boleh, didasarkan apa memperhitungkan perbedaan harga tersebut? Apakah mungkin perhitungan margin disesuaikan dengan tingkat inflasi dan deflasi yang terjadi atau diprediksi akan terjadi? Jelas ini amat susah bagi pihak bank untuk memperhitungkan, apalagi dengan pelayanan nasabah dalam jumlah yang banyak. Dengan demikian, dasar untuk membedakan harga tunai dengan harga kredit ialah karena adanya perbedaan pembiayaan operasional oleh bank. Artinya, semakin lama tenggang masa nasabah untuk menyelesaikan hutangnya, maka semakin banyak biaya operasional yang dikeluarkan oleh bank, baik biaya administrasi maupun gaji bagi karyawan. Walaupun

\footnotetext{
${ }^{36}$ Warkum Sumitro, Azas-azas Perbankan Islam \& Lembaga-lembaga Terkait: Bamui, Takaful dan Pasar Modal Syariah (Jakarta: RajaGrafindo Persada, 2004), h. 75.

${ }^{37}$ Aswath Damodaran, sebagaimana dikutip oleh Adiwarman, mendefinisikan time value of money dengan "A dollar today is worth more than a dollar in the future, because a dollar today can be invested to get a return". Ini juga menjadi asas penetapan bunga pada bank konvensional. Menurut Adiwarman, definisi ini tidak akurat karena setiap investasi selalu mempunyai kemungkinan untuk mendapat untung, rugi atau tidak untung tidak rugi. Itu sebabnya dalam teori keuangan (finance), selalu dikenal dengan risk-return relantionship (hubungan antara risiko dan pengembalian modal). Lihat Adiwarman, Bank Islam: Analisis Fiqh dan Keuangan (Jakarta: RajaGrafindo Persada, 2006), h. 376; Pandangan lain bahwa time value of money (nilai uang dipengaruhi oleh waktu) ini menjadi dasar perlu adanya bunga, dengan pertimbangan bahwa nilai \$ 1.000 hari ini tidak akan sama dengan \$ 1.000 sepuluh tahun ke depan. Atau dengan pertanyaan boleh dijawab dengan konsep tersebut, manakah yang perlu dipertimbangkan $\$ 1.000$ hari ini dengan $\$ 2.000$ sepuluh ke depan. James C. Horne \& John M. Wachowicz, Fundamentals of Financial Management (New Jersey: Prentice Hall, Upper Saddle River, 1998), h. 36.
} 
demikian sisi pandang seperti ini akan berada dalam ranah perbedaan pendapat di kalangan para ulama mazhab tentang biaya apa saja yang dibebankan kepada harga jual tersebut.

Ulama mazhab Maliki membolehkan biaya-biaya yang berkaitan baik langsung dengan transaksi jual beli maupun tidak langsung. Ulama mazhab Syâfiî membolehkan pembebanan biaya yang timbul dalam suatu transaksi jual beli, kecuali biaya gaji pegawai sendiri karena hal itu termasuk dalam keuntungannya. Begitu juga halnya dengan biayabiaya yang tidak menambah nilai barang, tidak boleh dimasukkan sebagai biaya. ${ }^{38}$ Ulama mazhab Hanafi membolehkan pembebanan biaya-biaya yang timbul dalam suatu transaksi jual beli, namun tidak membolehkan pembiayaan yang semestinya dikerjakan oleh si penjual. ${ }^{39}$ Sedangkan ulama Madzhab Hambali berpendapat bahwa semua biaya baik langsung maupun tidak langsung boleh dibebankan pada harga jual selama biaya-biaya itu harus dijelaskan kepada pihak ketiga dan akan menambah nilai jual barang tersebut. ${ }^{40}$

Perbedaan pendapat seperti di atas, tampaknya tetap menjadi pilihan bahwa harga jual dengan kredit memang harus berbeda dengan tunai. Dengan dasar perbedaan pembiayaan tersebut dianggap mempunyai tingkat kemudaratan teringan, dibandingkan alasan melarang oleh sebahagian ulama, yang itu pun ternyata berada pada ranah khilâfiyyah. Kenapa tidak didasarkan pada kaedah:

$$
\text { الأصل في المعاملات الإباحة حنى يدل الدليل على لـلهـا. }
$$

"Pada dasarnya segala bentuk mu'amalat boleh dilakukan kecuali ada dalil yang mengharamkannya."

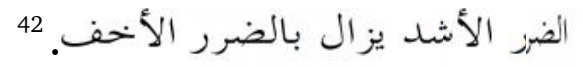

"Kemudaratan yang besar dapat dihilangkan dengan cara (melaksanakan) kemudaratan yang ringan."

Persoalan lain adalah, kenaikan harga dikarenakan mengangsur dan berdasarkan kepada perbedaan biaya operasional, maka muncul logika lain dan juga menjadi dasar bagi Warkum Sumitro sebagaimana tertuang di atas, yakni tentunya harus juga berpengaruh, seandainya terjadi percepatan untuk melunasinya sebelum berakhirnya masa angsuran. Artinya, bagi penabung yang ingin melunasi sisa angsuran sebelum jatuh tempo, maka harga barang seharusnya disesuaikan dengan perhitungan masa yang masih tersisa. Jadi kalau kenaikan itu dibatasi 10 persen pertahun, maka angsuran berkurang sebesar persentase yang masih ada tersebut. Namun dalam kenyatannya pada bank syariah, percepatan pelunasan

\footnotetext{
${ }^{38} \mathrm{Al}$-Syarbainî, Mughni al-Muhtâj, h. 78.

${ }^{39}$ Al-Kasânî, Bada'i wa Shana'i,, h. 223

${ }^{40} \mathrm{Al}$-Buhuti, Kasyf al-Qinâ' 'an Matn al-Iqnâ', h. 234; Karim, Bank Islam, h. 114.

${ }^{41}$ Abd al-Hamid Hakim, al-Bayân (Jakarta: Bulan Bintang, 1976), h. 198.

42‘Ali Ah̆mad al-Nadâwî, al-Qawâ 'id al-Fiqhiyyah (Damsyiq: Dâr al-Qalam, 1986), h. 276.
} 
yang dilakukan oleh nasabah sebelum habisnya masa angsuran, tidak memengaruhi harga barang, walaupun harganya berbeda karena berbedanya masa angsuran, kecuali hanya sekadar pemberian bonus saja dari bank untuk nasabah. ${ }^{43}$ Akhirnya, keinginan penabung untuk menyegerakan pelunasan, menjadi berkurang, walaupun mereka mampu. Karena melunasi sesuai masa tidak ada perbedaan secara signifikan, kecuali hanya bonus yang kadarnya tergantung kepada pihak bank semata. ${ }^{44}$

Menurut analisis lebih jauh, Islam sangat menganjurkan agar yang berutang untuk berupaya menyelesaikan utangnya sesegera mungkin kalau sekiranya telah mampu. Sesuai dengan sabda Rasulullah SAW. yang diriwayatkan oleh Imam Bukhârî dan Muslim dari Abû Hurairah:

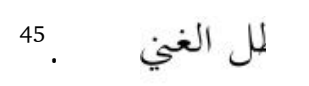

“Menunda pembayaran bagi orang yang mampu ialah kezaliman."

Kesimpulannya, tingginya harga barang karena lamanya masa mencicil, atau dalam istilah lain, kenaikan itu akan berbeda karena perbedaan masa angsuran. Berbedanya masa angsuran akan meningkatkan tambahan biaya oleh bank, sehingga akan memengaruhi harga barang. Sekiranya nasabah mempercepat pelunasan, tentunya biaya yang digunakan oleh bank akan berkurang, dan sangat tepat kalau juga memberikan akibat kepada berkurangnya utang. Namun itu bukanlah menjadi logika lebih jauh bagi bank syariah.

Di sanalah perbedaan antara meminjam uang kepada bank konvensional (akadnya utang piutang) dengan membeli barang kepada bank syariah (akadnya jual beli). Pada akad jual beli, kalau telah disepakati harga barangnya sekian, tidak bisa lagi dilakukan perubahan harga di belakang hari, kendati membedakan harga tunai dengan kredit didasarkan kepada perbedaan biaya operasional dan percepatan pelunasan mengakibatkan terjadinya pengurangan biaya. Sedangkan pada bank konvensional, jumlah utang memang didasarkan secara eksplisit kepada bunga yang diperhitungkan dengan masa/tempo.

Dengan demikian, agar benar-benar terlihat perbedaan antara skim yang ada pada kedua bank tersebut, dalam sistem akuntansinya bank syariah tidak dapat memilah secara jelas bahwa setiap kali angsurannya akan ada gambaran terpisah antara angsuran harga pokok barang dengan angsuran margin, bagaikan pada konvensional ada pengelompokan antara

${ }^{43}$ Wawancara dengan dua pegawai bank syariah berbeda.

${ }^{44}$ Wawancara dengan salah seorang pegawai bank syariah, menyatakan bahwa pada hakikatnya pihak bank tidak menginginkan penabung itu untuk menyegerakan pelunasan, karena akan dikhawatirkan penabung tersebut akan berpindah ke bank lain, akibat percepatan mengakhiri interaksi. Penulis juga tidak mendalami lebih jauh apa yang dimaksudkan, kecuali prinsip bank tidak ingin agar penabung menyegerakan pelunasan angsuran sebelum masa yang disepakati.

${ }^{45}$ Imam al-Bukhârî, Sahîh $\underline{h}$ al-Bukhârî, bab Matl al-Ghanî Dzulm, no. hadis. 2225, Juz VIII, Maktabah Shamilah: CD Room, h. 238; al-Kahlany, Subul al-Salam, Juz III (Bandung: Dahlan, t.t.), h. 61 . 
angsuran utang dengan bunga. Untuk itu juga, pola hitungan angsuran dengan anuitas ${ }^{46}$ pada bank syariah, dalam konteks itu, menjadi tidak urgen. ${ }^{47}$ Sebaliknya pada bank konvensional, pihak bank punya kepentingan dengan pola anuitas ini, dalam konteks yang sama, yakni percepatan pelunasan.

Kalau begitu, apa lagi yang menjadi dasar untuk perhitungan margin, selain masa? Berdasarkan wawancara dengan salah seorang pegawai bank syariah, lembaga yang berwenang merperhitungkan nilai mark-up terhadap barang pada akad murâbahah pada bank syariah itu ialah komisi penghitung jaminan dan aset (Asset Liability Committee, ALCO). Seperti pada bank konvensional, ALCO, yang terdiri dari direktur utama dan para manajer kunci yang aktif dalam kredit dan investasi. ALCO memiliki wewenang membuat keputusan dan mengatur aset dan jaminan, strategi harga atas pinjaman (pembiayaan), membuat cara pengaturan dana-dana dan menentukan pilihan untuk alokasi pinjaman (pembiayaan), serta menyusun action plan berdasarkan sebab berlakunya variasi. ${ }^{48}$

Untuk memperhitungkan margin atau mark-up harga barang, pada bank syariah biasanya menggunakan dua bentuk; menjadikan bunga bank konvensional sebagai ukuran (benchmark), dan/atau tingkat margin yang ditetapkan oleh bank syariah lain sebagai pesaing. ${ }^{49} \mathrm{Hal}$ ini sesuai dengan teori yang dikemukakan oleh Adiwaman A. Karim, ${ }^{50}$ bahwa ALCO bank syariah memiliki acuan dalam perhitungan margin, di antaranya ialah:

a. Suku bunga rerata perbankan konvensional. Tingkat suku bunga rerata perbankan konvensional, dikenal pula dengan istilah Inderect Competitor's Market Rate (ICMR), atau tingkat rerata suku bunga beberapa bank konvensional atau pada bank konvensional tertentu, yang dalam musyawarah ALCO ditetapkan sebagai kelompok pesaing, atau pesaing terdekat tidak langsung.

b. Margin rata-rata perbankan syariah. Tingkat margin rata-rata perbankan syariah yang dikenal pula dengan Direct Competitor's Market Rate (DCMR), atau tingkat margin rata-rata beberapa perbankan syariah yang ditetapkan oleh ALCO sebagai pesaing langsung. Dalam makna lain, tingkat margin keuntungan bank syariah yang ditetapkan dalam musyawarah ALCO sebagai pesaing langsung yang terdekat.

c. Target bagi hasil bagi penabung. Yang dimaksudkan ialah target bagi hasil kompetitif yang

${ }^{46}$ Pada setiap angsuran, porsi pokok semakin tinggi, sedangkan porsi margin semakin turun. Lihat Wiroso, Jual Beli Murabahah (Yogyakarta: UII Press, 2005), h. 113.

${ }^{47}$ Urgensi anuitas pada bank syariah, akan terlihat kepentingan bagi hasil untuk pihak ketiga (penabung), karena mereka akan mendapatkan bagi hasil yang besar pada awal transaksi murâbahah terjadi. Namun penerimaan bagi hasil, semakin lama akan menurun kalau bank tidak melakukan ekspansi lebih jauh dengan murâbahah yang lain.

${ }^{48}$ Kasmir, Dasar-dasar Perbankan (Jakarta: Raja Grafindo, 2003), h. 138; Zainul Arifin, Dasar-Dasar Manajemen Bank Syariah (Jakarta: Alvabet, 2002), h. 152-153.

${ }^{49}$ Wawancara dengan dua orang pegawai bank syariah berbeda.

${ }^{50}$ Karim, Bank Islam, h. 280-281. 
diharapkan untuk diberikan kepada dana pihak ketiga (Expected Competitive Return for Pelaburs /ECRI)

d. Biaya yang dikeluarkan oleh bank yang berkaitan langsung dengan upaya untuk memperoleh dana pihak ketiga.

e. Biaya yang dikeluarkan oleh bank yang tidak langsung berkaitan dengan upaya untuk memperoleh dana pihak ketiga.

Islam pada dasarnya tidak memberikan batasan yang kaku dalam penentuan harga barang. Artinya, Islam sangat memberikan kebebasan dan menghargai sistem operasi pasar bebas, sebagaimana hadis yang diriwayatkan oleh lima perawi, kecuali al-Nasâ̂̂, dari Anas:

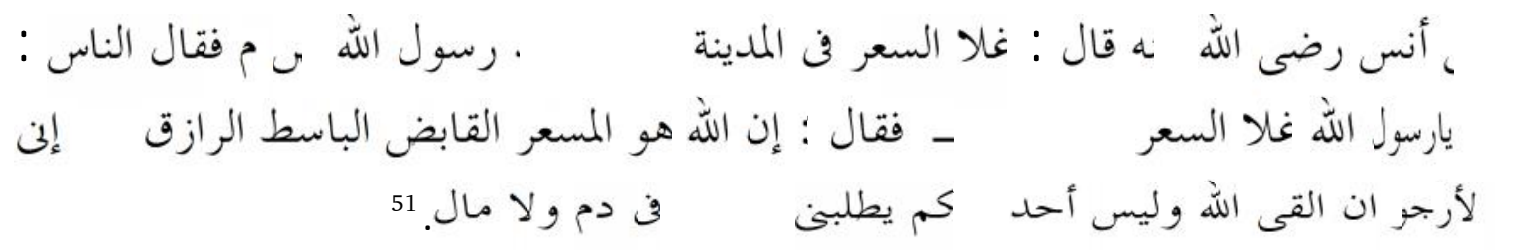

"Diriwayatkan dari Anas, dia berkata: Harga pernah naik dengan mendadak di Madinah pada masa Rasulullah SAW. Para sahabat berkata: Ya Rasulullah! Tentukan harga untuk kita. Rasulullah menjawab: Allah sesungguhnya ialah penentu harga, penahan dan pencurah serta pemberi rezki. Aku mengharapkan dapat menemui Tuhanku di mana salah seorang dari kalian tidak menuntutku karena kezaliman dalam hal darah dan harta."

Ada orang beranggapan bahwa apabila harga yang ditentukan oleh penjual itu berpuluh-puluh kali lipat, berarri menzhalimi pembeli. Artinya, menurut mereka penentuan harga yang sesuai dengan Islam ialah yang tidak boleh berlipat ganda. Hal ini susah dipahami, karena tidak ada ketentuan dalam Islam yang menggariskan demikian. Kecuali halnya harga yang berlipat ganda tersebut disebabkan karena penimbunan barang yang berpengaruh terhadap kelangkaan barang di pasaran. Secara rasional ialah harga barang yang sangat tinggi, akan memengaruhi daya beli masyarakat. Kalau peminat sebuah barang tidak ada atau sedikit karena harga yang mahal, sudah dapat dipastikan harga akan turun. Cara seperti inilah yang diterapkan pada sistem ekonomi modern masa sekarang. Namun Islam semenjak lama menggariskan bahwa harga barang dibiarkan ditentukan oleh pasar. Ini berarti cara bank syariah menentukan harga barang yang dijual dalam transaksi murâbahah misalnya, dengan mengambil perhitungan dari berbagai hal sebagaimana juga diperkuat oleh Adiwarman di atas, telah sesuai dengan ajaran Islam.

Bagaimana seandainya terjadi penyalahgunaan uang oleh penabung, sebagai wakil bank, yang sudah disepakati semula untuk pembelian barang kemudian dialihkan tanpa sepengetahuan pihak bank, maka pihak bank tidak dapat mengantisipasinya. Karena tidak

${ }^{51}$ Al-Kahlani, Subul al-Salâm, Juz III, h. 25. 
ada pola yang dapat memantau penabung kecuali jika bukti pembelian barang tersebut diserahkan kepada pihak bank. ${ }^{52}$

Sekiranya berlaku tunggakan dalam pembayaran angsuran, karena ketidakmampuan penabung, maka jalan keluar yang biasa dilakukan oleh bank syariah ialah dengan memperbaharui akad atau memperpanjang masa angsuran, sehingga nilai setiap angsuran menjadi lebih kecil, tanpa penambahan harga barang. ${ }^{53}$ Cara seperti itu jelas sangat sesuai dengan prinsip mu'amalah dalam Islam, karena adanya sifat menolong (ta'âwun) bagi penabung yang sedang dalam kesusahan. Akan tetapi apabila, penabung dengan sengaja memperlambat atau menunda-nunda pembayaran, padahal ia mampu melunasinya, maka penabung akan dikenakan denda sesuai yang disepakati. Denda yang dimaksud, sebagaimana yang termuat dalam contoh naskah akad pada bank syariah, oleh pihak bank syariah dijadikan sebagai dana sosial. ${ }^{54}$

Denda ini dikritik oleh Abdullah Saeed dalam bukunya, seperti juga penulis lainnya. Menurut mereka, sanksi atau "denda" menggambarkan kerugian yang diderita oleh bank akibat tidak dibayarnya utang tepat waktu. Bank syariah melihat adanya "tingkat laba secara normal" dengan adanya sanksi "denda" tersebut. Sehingga hal ini sama saja dengan tujuan-tujuan praktis sanksi bunga dalam bank konvensional, ketika utang tidak dibayarkan tepat waktu. ${ }^{55}$

Kritikan para pakar ini, tidak relevan dengan fakta yang ada di perbankan syariah Indonesia. Sanksi denda yang diterapkan dalam transaksi murâbahah yang sengaja lalai membayarkan angsurannya, tidak dapat disamakan dengan pola sanksi bunga yang ada di bank konvensional. Beberapa alasannya di antaranya:

a. Denda tersebut tidak dimanfaatkan sebagai bagian pendapatan bank, kecuali dimanfaatkan untuk aktivitas sosial;

b. Sanksi dimaksudkan lebih bersifat mendidik dan pencegahan untuk mengantisipasi kerugian pada bank, sebagai lembaga penghimpun dana publik (Dana Pihak Ketiga). Upaya pencegahan terhadap kemudaratan dalam Islam dapat dilandaskan kepada kaedah sadd al-dzarî́ah. ${ }^{56}$

${ }^{52}$ Wawancara dengan dua orang pegawai bank syariah berbeda.

${ }^{53}$ Ibid.

${ }^{54}$ Ibid.

${ }^{55}$ Saeed, Islamic Banking and Interest, h. 90; FIBE, 'Aqd Bai' al-Murâbahhah, dan Mohammed, Islamic Banks Practices in Murâbahah, makalah disampaikan dalam seminar tentang Ekonomi Islam di Abu Dabi, 18-20 Maret 1989.

${ }^{56}$ Sadd al-dzarî́ah dimaksudkan sebagai suatu metode istinbâth hukum dalam Islam dengan bentuk "menutup jalan agar jangan terjadi sesuatu kerusakan". Lihat 'Alî Hasballah, Ushûl al-Tasyri' al-Islâm (Mesir: Dâr al-Ma'ârif, 1971), h. 319, dan kitab-kitab ushul fiqih lainnya. Dalam konteks di atas, sanksi denda dimaksudkan sebagai upaya menutup jalan agar jangan timbulnya kerugian bagi bank dan penabung, akibat kelalaian pembayaran angsuran dengan sengaja. 
Dalam perspektif lain, yang menjadi kritikan lebih jauh terhadap bank syariah dalam menjalankan akad murâbaḩah ini ialah kecenderungan pihak bank melaksanakan akad ini hanya dari sisi kemudahan, atau adanya akad wakâlah yang dikondisikan. Pihak bank syariah lebih tergambar sebagai organisasi "pembiaya" bukan "penjual" barang, walaupun dalam transaksi murâbahah, bank harus berperan sebagai penjual. Penilaian ini muncul, karena bank tidak memegang barang dan tidak juga mengambil risiko di atasnya. Dengan memandang bank syariah pada sisi ini, kecenderungan sebagian orang menilai tidak ada bedanya dengan bank konvensional, agaknya dapat dibenarkan juga. Bagaikan penilaian Abdullah Saeed yang menyatakan bahwa meskipun murâbaḩah di awalnya sebagai kontrak jual beli, namun sebenarnya ini sejenis pembiayaan berdasarkan keuntungan yang ditetapkan di muka, yang tidak jauh berbeda dengan pembiayaan berdasarkan bunga tetap. ${ }^{57}$

\section{Penutup}

Dari uraian di atas, terlihat bahwa betapa dilematisnya bank syariah dalam menerapkan skim murâbahah ini, antara tuntutan ingin berada dalam nuansa syariah Islam secara murni, sehingga tereliminir persepsi miring sekadar ganti "baju," dengan tuntutan pragmatisme pasar dan realits sumber daya manusia bank. Dilema tersebut akan tereleminir kalau pengawasan dari Dewan Pengawas Syariah terhadap pelaksanaan skim di lapangan bisa lebih optimal lagi, dan kemauan dari praktisi untuk tidak hanya memandang dari segi kepraktisan dan kemudahan semata, melainkan bagaimana menempatkan paradigma syariah ini menjadi landasan utama dalam setiap transaksi yang ada di perbankan syariah.

\section{Pustaka Acuan}

Ab. Ghani, Ab. Mumin. Sistem Kewangan Islam dan Pelaksanaannya di Malaysia. Kuala Lumpur: Jabatan Kemajuan Islam Malaysia, 1999.

Arifin, Zainul. Dasar-dasar Manajemen Bank Syariah. Jakarta: Alvabet, 2002.

Al-Bahuti. Manshur bin Yûsuf. Kasyfal-Qinâ' 'an Matn al-Iqnâ', Juz. III. Beirut: Dâr al-Fikr, 1982.

Mohammed. Islamic Banks Practices in Murâbaḩah, Makalah di Abu Dabi, 18-20 Maret 1989.

Hakim Abd al-Hamid. al-Bayân. Jakarta: Bulan Bintang, 1976.

Hasballah. 'Alî. Ushûl al-Tasyri' al-Islâm. Mesir: Dâr al-Ma'ârif, 1971.

Himpunan Fatwa Dewan Syari'ah Nasional MUI, Edisi Revisi Tahun 2006.

Horne, James C. \& Wachowicz, John M. Fundamentals of Financial Management, New Jersey: Prentice Hall, Upper Saddle River, 1998.

${ }^{57}$ Saeed, Islamic Banking and Interest, h. 92. 
Ibn 'Abidîn. Radd al-Mukhtâr 'ala al-Ardh al-Mukhtâr, Juz IV. t.tp.: t.p., t.t.

Ibn 'Arabi. Anhkâm al-Qur'ân, Juz I, Kairo: 'Îsa al-Bâbî al-Halabi wa Syurakah, 1967.

Ibn Majah, Sunan Ibn Mâjah, Juz II. Kairo: Mathba'ah Dâr Ihya' al-Kutub al-'Arabiyah, t.t.

Ibn Manshur, al-Afriqy. Lisân al-Árab, Juz II. Beirut: Dâr al-Sadr, t.t.

Ibn Qudamah, Abû Muhammad bin Ahmad. al-Mughny, Juz.IV. Riyadh: Riasah Idarah al-Buhuts al-'Ilmiyyah wal al-Ifta ' wa al-Da'wah wa al-Irsyâd, 1401 H.

Ibn Rusyd, Abû al-Wâlid Muhammad. Bidâyah al-Mujtahid wa Nihâyah al-Muqtashid, Juz II. Kairo: Syarikah Maktabah wa Mathba'ah Musthafa al-Bâbî al-Halabi wa Auladih, 1981.

Imam al-Bukhari, Shahîh al-Bukhârî, Juz VIII, Maktabah Shamilah: CD Room.

Iska, Syukri. "Dilematis Lembaga Perbankan Syariah Dalam Kultur Minangkabau”, dalam Jurnal Ilmiah Syariah (Juris), STAIN Batusangkar, Vol. 5, No. 1/2006.

Al-Jaziri, Abd al-Rahman, Kitâb al-Fiqh 'alâ al-Madzhâhib al-Arba'ah, Juz II, Bairut: Dâr Ihya' al-Turats al-'Arabî, 1986.

Al-Kaff. Does Islam Assign Any Value, dan CII., Consolidated Recommendations on the Islamic Economic System. Islamabad: Council of Islamic Ideology, 1983.

Al-Kahlany. Muhammad ibn Ismấîl Subûl al-Salâm, Juz III. Bandung: Dahlan, t.t.

Karim, Adiwarman A. Bank Islam: Analisis Fiqh dan Keuangan. Jakarta: RajaGrafindo Persada, 2006.

Al-Kasânî, Abû Bakr Ibn Mas'ud. al-Badâ’i wa al-Shanâ’i fî Tartîb al-Syarấi, Juz VII. Beirut: Dâr al-Kitab al-'Arabî, t.t.

Kasmir. Dasar-dasar Perbankan. Jakarta: RajaGrafindo, 2003.

Kuwait Finance House. al-Fatâwâ al-Syar'ìyyah fí al-Masâil al-Iqtishâdiyyah. Kuwait: KFH, 1985-1986 \& 1986-1987.

Al-Marghinani, Burhan al-Dîn. al-Hidâyah Syarh Bidâyah al-Mubtady. Juz III. Kairo: Syarikah Maktabah wa Mathba'ah Musthafa al-Bâbî al-Halabî wa Auladih, t.t.

Al-Misr. Masraf al-Tanmiyyat al-Islâmiy. Beirut: Mu'assasat al-Risalah, 1997.

Al-Nadawi, 'Alî Ahmad. al-Qawầ 'id al-Fiqhiyyah. Damsyiq: Dâr al-Qalam, 1986.

Al-Râzî, Abû 'Abd Allâh Muhammad Fakhr. al-Tafsîr al-Kabîr, Juz VII. Kairo: al-Matba'ah al-Bahiyyah, 1938.

Saeed, Abdullah. Islamic Banking and Interest: A Study the Prohibition of Riba and its Contemporary Interpretation. Leiden: E.J. Brill, 1996.

Al-Syâfi'î, Muhammad Idrîs. al-Umm, Juz. III. Beirut: Dâr al-Ma'rifah, 1973

Al-Syarbini, Muhammad al-Khatib. Mughni al-Muhtâj 'alâ Ma'arif Ma'âni Alfazh al-Minhâj. Kairo: Syarikah Maktabah wa Mathba'ah Musthafa al-Bâbî al-Halabi wa Awladih, 1958.

Al- Syaukânî, Muhammad. Nail al-Authâr, Juz. V. Kairo: Maktabah al-Da'wah al-Islamiyyah, t.t. 
Syukri Iska: Dilema Skim Murabahah Pada Perbankan Syariah

Syihata, Syauqy Ismâ‘̂̂l. Nazhariyyat al-Muhâasabah al-Mâliyyah min Mandûrin Islâmi, Kairo: al-Zahra li al-I'lam al-'Arabi, 1987

Sumitro, Warkum. Azas-azas Perbankan Islam \& Lembaga-lembaga Terkait: Bamui, Takaful dan Pasar Modal Syariah. Jakarta: RajaGrafindo Persada, 2004.

Wiroso. Jual Beli Murâbahah. Yogyakarta: UII Press, 2005.

Al-Zarqa.' al-Madkhal al-Fiqh al-Ầm, Juz I (al-Fiqh al-Islâmi fi Tsawbih al-Jadîd), Beirut: Dâr al-Fikr, 1968. 